2000 and there acts as an oxygen carrier rather than as a catalyst. It is probably the only one to which we can assign a net requirement. For the others, requirements have to be expressed in terms of the amount in the feed, that is as $\mathrm{mg} / \mathrm{kg}$ dry matter.

Arnon's three tests of essentiality of an element for plants are (I) the life-cycle cannot be completed if it is absent, (2) its action must be specific and not replaceable by that of another element, (3) its effect on the plant must be direct. I think that these same criteria should be applied to tests of essentiality for animals. The difficulty lies in the application of such tests to higher animals.

\title{
Trace elements in Scottish soils
}

\section{By R. L. Mitchell, The Macaulay Institute for Soil Research, Craigiebuckler, Aberdeen}

Realization of the importance of certain trace elements in animal nutrition has led to a requirement for maps or other means of ascertaining the probable trace-element status of the soils of any locality. The more important factors which ultimately determine the amount of any trace element supplied to the grazing animal through the herbage are: (I) the total content in the soil and in the parent material from which the soil was derived, (2) the proportion of the total content capable of being utilized by the plant and (3) the relative uptakes of the various herbage species concerned.

In regions with extensive areas of soils derived from a fairly uniform parent material, such as the great continental plains, the trace-element status of the soil can often, as pointed out by Vinogradov (1959), be related directly to pedological factors and be readily mapped on small-scale maps, but in Scotland conditions are somewhat different, and such generalizations are impossible. Scotland is an area of complex geology, in which the parent rocks contain very variable amounts of the trace elements of biological importance, and the factor of primary importance is generally the soil parent material, although local soil conditions cannot be disregarded. In addition to igneous rocks of all types from ultrabasic to acidic, there occur arenaceous and argillaceous sedimentary rocks and limestones as well as metamorphic rocks of both igneous and sedimentary origin, sometimes in relatively small exposures. To complicate the picture further, several periods of glaciation have produced a surface drift, from which the soils have developed. This drift may have been transported some distance and may indeed be a mixture of several rock types rather than a derivative of the existing underlying rock.

\section{Trace elements in soil parent materials}

Before considering the distribution of the biologically important trace elements in Scottish soils, it is necessary to look briefly at the factors controlling their occurrence in rocks. The igneous rocks, from which both sedimentary and metamorphic 
rocks have been subsequently derived, originated by a process of fractional crystallization from a silicate magma. The factors controlling the distribution of trace elements in rocks have been studied intensively (Goldschmidt, 1954) and the probable trace-element content of any igneous rock is known. Trace elements are located in the major rock-forming minerals whose crystal lattices can accommodate them, as a result of substitution for elements of similar ionic radius which are major constituents of the minerals. Thus cobalt and nickel both occur in ferromagnesian minerals such as olivines and hornblendes, replacing magnesium or iron, because all have ionic radii of approximately $0.8 \AA$. It is therefore in basic and ultrabasic rocks that the highest contents of $\mathrm{Co}$ and $\mathrm{Ni}$ are found, as suitable ferromagnesian minerals are characteristic of these rocks. These elements, on the other hand, tend to be scarce in later-crystallizing acid igneous rocks such as granites, which in turn may have high contents of barium or lead, which substitute in potassium minerals as these metals all have ionic radii near to $\mathrm{r}_{3} 3 \AA$. Similar considerations account for the distribution of most trace elements in igneous rocks. A number of detailed discussions of the factors involved are available, including those of Nockolds \& Mitchell (1948) and Wager \& Mitchell (195I).

Among sedimentary rocks the chief soil parent materials are the argillaceous shales and slates and the arenaceous sandstones and related rocks. Elements of particular biological importance, such as cobalt and copper, as well as those which may be deleterious to stock when present in excessive amount, such as molybdenum and selenium, tend to be concentrated in argillaceous sediments. Such rocks are seldom inherently low in trace elements. The sandstones and the light sandy soils derived from them, on the other hand, are often low in trace elements. It should be mentioned that the Old Red Sandstone rocks of Scotland include argillaceous as well as arenaceous strata, Old Red Sandstone being a generic name for a geological epoch and not necessarily descriptive of the individual rocks themselves, although sandstones are typical of the formation. The factors, such as ionic potentials, involved in the distribution of trace elements in sediments, following the weathering of igneous rocks, have been discussed briefly elsewhere (Mitchell, r955).

The total trace-element content of metamorphic rocks depends on that of the rocks from which they were formed by heat or pressure; the trace elements may, however, be present in different mineral combination and the modified rate of weathering of these minerals is a factor which must be kept in mind in considering subsequent soil behaviour. For instance, boron may be fixed in metamorphosed sediments.

\section{Trace elements in the soil}

It is thus possible, knowing the nature of its parent rock, to predict with some accuracy the likely level of the total trace-element content in any soil, or, at worst, to explain any marked deviation from the expected content. Knowledge of the total content of any trace element in a soil is of much greater significance than is that of the corresponding value for a major nutrient, chiefly because variation in the content of most trace elements in soils is far greater than the variation of elements such as 
potassium, calcium or phosphorus. Differences of a hundred- or of even a thousandfold may occur in the total content of trace elements from soil to soil compared with only several-fold differences for the major elements. This significance, however, seldom justifies accurate determinations of the total trace-element contents. A semi-quantitative assessment or even a knowledge of the nature of the parent material will give sufficient information. Deficiencies of Co are unlikely in soils of basic or ultrabasic igneous origin, in which the total contents will lie above 30 p.p.m., and in which the $\mathrm{Co}$ is contained in relatively readily weathered ferromagnesian minerals. The rate of release from the constituent minerals is an important factor. The distribution of $\mathrm{Cu}$ in igneous rocks is more uniform. Deficiency of $\mathrm{Co}$, and often also of $\mathrm{Cu}$, is liable to occur on soils derived from sandstones or other arenaceous rocks which are inherently low in $\mathrm{Co}$ and $\mathrm{Cu}$, and where such trace elements as are present may occur in less readily weathered minerals, such as iron oxides. In Scotland, this situation is exemplified by the Co deficiency of sheep and $\mathrm{Cu}$ deficiency of cereals grown on sandy soils from the Black Isle, the Moray Firth coast, the Turriff district of Aberdeenshire and the Western Isles, although in the latter area other factors may also be involved. Low total contents of Co may also occur in soils of granitic origin, such as those around the Criffel granite in the Solway area and in certain Aberdeenshire granites, but all granites or granitic gneisses are not inherently low in Co. Many of the metamorphic rocks of the north-west are suspect.

Total contents of the order of I p.p.m. Co or $\mathrm{Cu}$, typical of light sands, are more than sufficient, if availability were complete to provide adequately supplied crops, containing $0 . \mathrm{I}$ p.p.m. Co or Io p.p.m. Cu, over a number of years. At the high crop removal rate of Io tons/acre/year, such a total content of $\mathrm{Co}$ in the crop could be sustained without replacement for rooo years and of $\mathrm{Cu}$ for Io years. A 'so-called' deficient soil is seldom, if ever, inherently deficient. The Mo content of Scottish soils seldom exceeds 3 p.p.m., but a $\mathrm{I}-2$ p.p.m. content in the crop is maintained without any addition, although the level of adequacy for most plants lies at about one-tenth of this concentration. The danger throughout Scotland is that indiscriminate addition of Mo in fertilizers may raise the soil status sufficiently to lead to disorders due to Mo excess in stock by raising the herbage content above 5 p.p.m. Mo. No instance of Mo deficiency in agricultural crops in Scotland has been recorded, although it may occur in some horticultural crops on light soils.

Pedological factors affect the availability of trace elements by influencing the rate of weathering of soil minerals and controlling the conditions of plant uptake. These conditions can also be affected by agricultural practices. The amount of certain trace elements taken up by the plant is related to the soil $\mathrm{pH}$. Liming can change markedly the plant content of some trace elements and in all pasture species the uptakes of $\mathrm{Co}, \mathrm{Ni}, \mathrm{Mn}$ and to a lesser extent of $\mathrm{Zn}$ are reduced, whereas that of Mo is increased. A pH change of $\mathrm{I}$ unit from 5.4 to 6.4 may reduce the content of Co, $\mathrm{Ni}$ or $\mathrm{Mn}$ to half and raise that of Mo several-fold (Mitchell, 1947). It does not follow that liming will necessarily reduce the Co content of a mixed pasture herbage, as it may alter the proportions of the various constituents of the herbage in such a way that the relative amounts of the species with higher Co contents are increased, 
and so keep the average Co level unchanged or even increase it, despite the fact that the contents of all its constituents are reduced. Similarly, any fertilizer that alters the balance of species in a mixed herbage may change its trace-element content without affecting the uptake of individual species.

Under Scottish conditions the pedological factor which influences mobilization of trace elements to the greatest extent is soil drainage. Where poor drainage has led to the development of gleyed soils, there is a considerably larger content of extractable trace elements than in neighbouring soils of identical parent material developed under conditions of free drainage. This effect is shown both by profile studies (Swaine \& Mitchell, I960) and field experiments (Mitchell, Reith \& Johnston, 1957) and some results from the latter investigation (Table I) indicate the magnitude of the effect. The effect is one of increased mobilization of trace elements from the constituent minerals in the poorly drained soils, not of removal from the freely drained soils.

Table I. Effect of soil drainage conditions on the trace-element content of soils (p.p.m.) and plants (p.p.m. in dry matter)

\begin{tabular}{|c|c|c|c|c|c|c|c|c|c|c|c|c|}
\hline \multirow{4}{*}{$\begin{array}{c}\text { Trace } \\
\text { element }\end{array}$} & \multicolumn{4}{|c|}{ Soil derived from argillaceous schis } & & & & & & & & \\
\hline & \multirow{2}{*}{\multicolumn{2}{|c|}{$\begin{array}{l}\text { Extracted } \\
\text { with } \\
\text { acetic acid* }\end{array}$}} & \multirow{2}{*}{\multicolumn{2}{|c|}{$\begin{array}{l}\text { Extracted } \\
\text { with } \\
\text { EDTAt }\end{array}$}} & \multicolumn{8}{|c|}{ Herbage } \\
\hline & & & & & \multicolumn{2}{|c|}{ Mixed } & \multicolumn{2}{|c|}{ Rye-grass } & \multicolumn{2}{|c|}{ Cocksfoot } & \multicolumn{2}{|c|}{ Red clover } \\
\hline & $\bar{G}$ & $\vec{P}$ & $G$ & $\mathbf{P}$ & $\widehat{G}$ & $\mathbf{P}$ & $\mathrm{G}$ & $\vec{P}$ & G & $\overrightarrow{\mathbf{P}}$ & G & $\vec{p}$ \\
\hline $\begin{array}{l}\text { Cobalt } \\
\text { Nickel } \\
\text { Zinc } \\
\text { Copper } \\
\text { Molybdenum } \\
\text { Manganese }\end{array}$ & $\begin{array}{l}1 \cdot 0 \\
1 \cdot 0 \\
3 \cdot 5 \\
0.13 \\
0.04 \\
-\end{array}$ & $\begin{array}{l}2.7 \\
5.6 \\
6.3 \\
0.98 \\
0.06 \\
-\end{array}$ & $\begin{array}{l}0.3 \\
1 \cdot 1 \\
3.8 \\
1.7 \\
0.07 \\
7.0\end{array}$ & $\begin{array}{c}2.0 \\
4.1 \\
<10 \\
6.8 \\
0.14 \\
10.2\end{array}$ & $\begin{array}{l}0.12 \\
0.9 \\
24 \\
3.6 \\
1.5 \\
47\end{array}$ & $\begin{array}{r}0 \cdot 86 \\
2 \cdot 3 \\
26 \\
4 \cdot 1 \\
1 \cdot 7 \\
134\end{array}$ & $\begin{array}{l}0.11 \\
0.9 \\
25 \\
3 \cdot 2 \\
1 \cdot 3 \\
62\end{array}$ & $\begin{array}{l}0 \cdot 64 \\
2 \cdot 1 \\
21 \\
2 \cdot 6 \\
1 \cdot 0 \\
92\end{array}$ & $\begin{array}{l}0.13 \\
0.9 \\
22 \\
4 \cdot 3 \\
1 \cdot 2 \\
70\end{array}$ & $\begin{array}{c}0.73 \\
2.4 \\
18 \\
4 \cdot 8 \\
1 \cdot 4 \\
182\end{array}$ & $\begin{array}{l}0.17 \\
1 \cdot 0 \\
35 \\
8 \cdot 9 \\
2 \cdot 0 \\
33\end{array}$ & $\begin{array}{r}1 \cdot 2 \\
3 \cdot 0 \\
37 \\
10 \cdot 2 \\
2 \cdot 4 \\
46\end{array}$ \\
\hline
\end{tabular}

Examples of mobilization of Mo have also been observed, generally in poorly drained soils where there has been some accumulation of organic matter, in amounts sufficient to give herbage contents of over Io p.p.m. The almost complete infertility of certain small areas in Aberdeenshire arises from excessive contents of extractable $\mathrm{Ni}$, associated with poorly drained soils of ultrabasic origin. This condition can be counteracted by liming. Other pedological effects of lesser significance are discussed by Swaine \& Mitchell (1960).

Peat and organic soils are often low in available trace elements, but zones of trace-element accumulation may occur in deep peats (Mitchell, 1954), and it is not possible to generalize.

In studying any trace-element problem one must take into consideration both the nature of the soil parent material and the local pedological conditions. A local, and sometimes a field-to-field, knowledge is required, and it is quite impossible, as certain commercial interests have suggested, to produce maps or diagrams that indicate the trace-element status on the basis of crude geographical units such as counties which bear no relationship to the factors concerned. A soil survey map on the scale of $I$ in. to I mile is probably the smallest that can give the full background information, when used in conjunction with the relevant soil memoir. The detailed survey of 
Scottish soils is at present in progress, but so far only nine sheets have been published and for one or two the memoirs are not yet available. It is desirable in most instances to call on the experience of local agricultural advisers, backed by analytical determinations, before applying any trace-element treatment to soils.

In order to assess the ability of a soil to supply trace elements to the plant some extraction technique must be employed. It can be either chemical or biological. The plant itself is obviously the best criterion, but plants are not always available, and their composition is affected by various factors such as time of sampling. A chemical extractant simulating plant uptake is desirable and many investigations have been carried out to determine the most suitable extractant for the various elements. Under Scottish conditions dilute acetic acid $\left(2 \cdot 5 \%(\mathrm{v} / \mathrm{v}) \mathrm{CH}_{3} \mathrm{COOH}\right)$ is reasonably effective in diagnosing the Co status of the soil, and is useful also for $\mathrm{Ni}, \mathrm{Zn}$ and many of the metals which may be toxic when in excess. For $\mathrm{Cu}$ the best correlation appears to be obtained with a dilute ethylenediaminetetraacetic acid (EDTA) extractant (Mitchell et al. 1957), and for Mo there are several possible reagents depending on field conditions.

No reagent can achieve a precise correlation with the plant, if only because no two plant species show the same relative uptakes from different soils or a similar distribution of trace elements in different parts of the plant. It is probably relevant to examine some of these effects more closely.

\section{Trace-element uptake of herbage plants}

The composition of the herbage consumed by the grazing animal, as far as its trace-element content is concerned, is related not only to soil factors which can be assessed with a considerable degree of accuracy, but also to seasonal changes in plant composition, to the variations in the relative amounts of different species in the sward throughout the season, to the stage of maturity of the crop and to climatic factors affecting growth.

Different species take up different amounts of trace elements even when growing in intimate admixture, as illustrated by the figures in Table 2 taken from Mitchell ( 1948 ). The relative contributions of the different species to the mixed herbage vary at different stages of growth. The effect of the soil conditions on the relative traceelement contents can be illustrated by two examples. At normal or high $\mathrm{Co}$ or $\mathrm{Cu}$ levels, the clovers generally have higher contents than the grasses, but at low levels the position is reversed, the clovers showing considerably lower contents than the grasses, as Table 3 demonstrates. It is therefore not necessarily desirable to include

Table 2. Trace elements in the constituent species of a mixed pasture herbage as p.p.m. in dry matter

$\begin{array}{lccccccc}\text { Herbage } & \text { Cobalt } & \text { Nickel } & \text { Zinc } & \text { Copper } & \text { Molybdenum } & \text { Manganese } & \text { Strontiun } \\ \text { Mixed } & 0.16 & 1 \cdot 74 & 38 & 9 \cdot 9 & 0.49 & 95 & 19 \\ \text { Rye-grass } & 0.20 & 1 \cdot 38 & 33 & 6.0 & 0.32 & 59 & 12 \\ \text { Cocksfoot } & 0.14 & 0.93 & 25 & 5.8 & 0.53 & 101 & 6 \\ \text { Red clover } & 0.26 & 2.82 & 92 & 17.5 & 0.35 & 56 & 66\end{array}$


Table 3. Plant uptake (in p.p.m. dry matter) of cobalt and copper from an untreated plot and from one that had received $3 \mathrm{lb}$ cobalt sulphate and $40 \mathrm{lb}$ copper sulphate/acre

\begin{tabular}{lcccc}
\multicolumn{1}{c}{ Herbage } & \multicolumn{2}{c}{ Cobalt } & \multicolumn{2}{c}{ Copper } \\
Mixed & 0.06 & 0.62 & Untreated & Treated \\
Rye-grass & 0.06 & 0.56 & 3.4 & 5.6 \\
Cocksfoot & 0.06 & 0.59 & 2.4 & 3.2 \\
Crested dogstail & 0.05 & 0.59 & 3.5 & 4.0 \\
Timothy & 0.03 & 0.25 & 2.8 & 3.7 \\
Red clover & 0.04 & 0.87 & 2.7 & 3.4 \\
& & & 1.4 & 7.8
\end{tabular}

a preponderance of clover in a herbage mixture on a deficient soil, as might at first sight appear desirable. Although the Co content of the constituents of a mixed herbage on a normal soil increases in the order timothy, cocksfoot, rye-grass, red clover, it is not always so, as shown in Table 4, for one soil carries cocksfoot with a very high Co content. The reason has not been established, but it may be related either to the form in which the available Co is present or to the stages of maturity of the plants.

'Table 4. Comparison of cobalt contents as p.p.m. in dry matter of mixed pasture herbage and its constituent species on different arable soils

\begin{tabular}{lcccc} 
Herbage & \multicolumn{5}{c}{ Soil } & \\
Mixed & I & 2 & 3 & 4 \\
Clover & 0.04 & 0.17 & 0.10 & 0.26 \\
Rye-grass & 0.08 & 0.35 & 0.19 & 0.18 \\
Cocksfoot & 0.04 & 0.11 & 0.08 & 0.06 \\
& 0.03 & 0.12 & 0.09 & 0.36
\end{tabular}

Space prohibits more than mention of the finding that different plant parts, or even differently located leaves, may contain vastly different contents of certain trace elements, such as $\mathrm{Zn}$ or Mo, and that though the leaf may have the highest absolute content, the stem or seed head of a grass may contribute more to the diet of the animal consuming it. Which part is more readily assimilated is a question which must be left to the veterinarian or the nutritionist. It may be worth while pointing out, in this connexion, that a fenced-off portion of a field is only a reliable index of what is available to the animal if it is regularly cut to simulate grazing.

The foregoing brief survey may serve to demonstrate why it is not feasible to give a simple account of trace-element distribution in Scottish soils on a geographical basis. It is necessary to have a reasonably clear picture of the actual soil type in question before it is possible to assess the probable level of the biologically important trace elements, and if there is any doubt, workers with an intimate knowledge of local conditions should be consulted. The problems which arise in the investigations of hill soils have been examined by Calder \& Voss (1957), who point out the difficulties of obtaining representative herbage samples.

\section{REFERENCES}

Calder, A. B. \& Voss, R. C. (1957). The sampling of hill soils and herbage, with particular reference to the determination of the trace elements. Consultative Committee for Development of Spectrographic Work, Bulletin no. I. Aberdeen: The Macaulay Institute for Soil Research. 
Goldschmidt, V. M. (1954). Geochemistry. Oxford: Clarendon Press.

Mitchell, R. L. (1947). Proc. int. Congr. Chem. xi. London, 3, I 57.

Mitchell, R. L. (1948). Research, I, I 59.

Mitchell, R. I. (1954). Proc. int. Peat Symp., Dublin, Section B3.

Mitchell, R. L. (1955). In Chemistry of the Soil (Monogr. Ser. Amer. chem. Soc. no. 126), p. 253. [F. E. Bear, editor.] New York: Reinhold Publishing Corp.

Mitchell, R. L., Reith, J. W. S. \& Johnston, I. M. (1957). F. Sci. Fd Agric. 8, S5I.

Nockolds, S. R. \& Mitchell, R. L. (I948). Trans. roy. Soc. Edinb. 61, 533.

Swaine, D. J. \& Mitchell, R. L. (1960). F. Soil Sci. (In the Press.)

Vinogradov, A. P. (1959). The Geochemistry of Rare and Dispersed Chemical Elements in Soils. New York: Consultants Bureau.

Wager, L. R. \& Mitchell, R. L. (195 I). Geochim. et cosmoch. Acta, r, 129.

\title{
Biochemical function of some of the minor elements
}

\author{
By E. C. Owen, Hannah Dairy Research Institute, Kirkhill, Ayr
}

Since copper, molybdenum, sulphur and selenium are being discussed by others the present paper deals with cobalt, zinc, cadmium, manganese and vanadium.

\section{Cobalt}

Vitamin $B_{12}$ (Smith, I957) is needed by non-ruminants to prevent anaemia and ensure optimal growth on food of vegetable origin, and Co is needed by ruminants to enable their symbiotic bacteria to make vitamin $B_{12}$. It is possible also that all these species need $\mathrm{Co}$ in forms other than vitamin $\mathrm{B}_{12}$ since cobaltous ions can activate a number of enzymes (Gajdos, I959; Seekles, I948a-c). Absence of sufficient vitamin $B_{12}$ from human diet or incapacity to absorb it adequately from the food causes pernicious anaemia (PA) in man. PA when fully developed is characterized by a reduced number of circulating red blood cells that have a higher mean diameter and greater range in size than normal. There are also: ( $\mathrm{I}$ ) compensatory hypertrophy of the blood-forming tissues in the marrow of the long bones, (2) a changed histological picture of the bone marrow (obtained by sternal puncture) and (3) an atrophy of the stomach wall accompanied by achlorhydria and failure to produce Castle's intrinsic factor (IF). There may also be neuropathological symptoms aggravated or even precipitated by folic-acid therapy. The marrow cells need both folic acid and vitamin $B_{12}$ for normal erythropoiesis, and folic acid probably prevents the marrow from getting its full share of a poor supply of vitamin $B_{12}$ (Wintrobe, I956). The megaloblastic anaemia of vitamin $B_{12}$ deficiency can be due to abnormalities of the stomach, to a dietary deficiency or to inhibition of normal vitamin $\mathrm{B}_{12}$ absorption, by bacteria in the small intestine, as in sprue (Halsted, Carrol \& Rubert, I959).

Heathcote \& Mooney (I958) think that IF is not really intrinsic but is a peptide resulting from the digestion of vitamin $B_{12}$-protein complexes in the food. This heterodox view would make the absence of IF merely an effect of achlorhydria. Concentrates of the stomach mucosa of the pig and rat containing IF activity are effective in man, but their chemical nature (Keuning, Arends, Mandema \& Nieweg, I959) and mode of operation (Wolff \& Vuillemin-Weis, I958; Taylor, Mallett, Witts \& Taylor, 1958; Grasbeck \& Nyberg, 1958; Herbert, 1959) are still in dispute. 